\title{
ROLA POLUDNIOWEJ GALII \\ W PRODUKCJI I HANDLU WINEM W VI W. P.N.E. - II W. N.E. NA TLE PRZEMIAN POLITYCZNYCH W ZACHODNIEJ CZESŚCI MORZA ŚRÓDZIEMNEGO
}

\author{
ROLE OF SOUTHERN GAUL IN WINE PRODUCTION AND \\ TRADE IN 6th CENTURY B.C. - 2nd CENTURY A.D. IN \\ THE LIGHT OF POLITICAL CHANGES IN THE WESTERN \\ MEDITERRANEAN
}

\author{
Agnieszka Góralczyk \\ https://orcid.org/0000-0002-6900-1488 \\ e-mail: agnieszka785@gmail.com \\ Instytut Archeologii i Etnologii PAN \\ Al. Solidarności 105, 00-140 Warszawa
}

\begin{abstract}
The article describes the role of southern Gaul in the production and trade of wine, with particular consideration for the Gauloise flat-bottomed amphorae produced in this area. It provides a brief outline of the history of this area of Mediterranean basin, shaped by the political and economic activities of several Mediterranean peoples - Phoenicians, Greeks, Carthaginians, Etruscans and Romans. It discusses the types of archaeological sites where the remains of amphorae for Gallic wine were discovered, exemplary stamps characteristic of southern Gaul and the influence of the Romans on the emergence and development of the culture of producing and consuming wine in southern Gaul.
\end{abstract}

KEY WORDS: amphorae for wine, wine, grapevine, Gauloise 1, Gauloise 2, Gauloise 3, Gauloise 4, Gauloise 5, stamps, ceramics, Massalia, Narbo Martius, Gaul, Gallia Narbonensis

\section{HISTORIA POLUDNIOWEJ GALII KSZTALTOWANA PRZEZ POLITYKE I EKONOMIE}

Morze Śródziemne stwarzało możliwości rozwoju wszystkim tym ludom, które swoją pomysłowość, ciekawość świata i odwagę potrafiły wykorzystać do doskonale- 
nia umiejętności budowania statków i okrętów oraz sztuki żeglarskiej. Dalekomorskie podróże otwierały nowe perspektywy - dla ekspansji handlowej lub politycznej - Fenicjanom, Grekom i Kartagińczykom, którzy kolonizowali wybrzeża zachodniej części Morza Śródziemnego od 1 połowy I tysiąclecia p.n.e. (Tuñón de Lara, Valdeón Baruque, Domínguez Ortiz, 1997, s. 27-28). Feniccy kupcy jako pierwsi założyli swoje faktorie na Półwyspie Iberyjskim i od VIII w. p.n.e. wprowadzili do wymiany handlowej greckie produkty rzemieślnicze. Potem działalnością handlową w tym rejonie zajmowali się Rodyjczycy i Fokajczycy, ale tylko w przypadku Fokajczyków można mówić o kolonizacji wybrzeży Półwyspu Iberyjskiego oraz obecnej Prowansji (Tuñón de Lara, Valdeón Baruque, Domínguez Ortiz, 1997, s. 29-30). Pod koniec VIII w. p.n.e. wzrosło znaczenie i dobrobyt miast Etrurii. Etruskowie za pośrednictwem Greków osiadłych w Wielkiej Grecji oraz kupców fenickich włączyli się w handel śródziemnomorski. Etruskie miasta położone na wybrzeżu morskim zainteresowane były stworzeniem własnej floty handlowej, co nastąpiło w VII w. p.n.e. Wówczas Etruskowie wyruszyli na wyprawy handlowe wzdłuż brzegów Morza Tyrreńskiego, potem do Galii i na Półwysep Iberyjski (Cunliffe, 2003, s. 62).

Etruscy kupcy zakładali swoje placówki handlowe na terenie dzisiejszej Prowansji i Langwedocji. Szybko jednak na obszarze zdominowanym przez Etrusków zaczęli pojawiać się Grecy (głównie Fokajczycy) i to oni przejęli dominującą rolę w handlu w tym rejonie, co rzecz jasna nie wykluczało importu wyrobów etruskich, równie cenionych jak greckie. Pierwszą kolonią grecką stała się założona przez Fokajczyków w 600 r. p.n.e. Massalia (Marsylia), na wybrzeżu obecnej Prowansji. Koloniści massalscy założyli następnie: Emporion (Ampurias w dzisiejszej Katalonii) i Agathe (Agde na terenie obecnej Langwedocji) w V w. p.n.e. oraz Tauroeis, Olbię i Nikaję (Niceę) w IV w. p.n.e. (wszystkie na obszarze dzisiejszej Prowansji). Najważniejszą kolonią stała się Massalia ze względu na swoje położenie geograficzne blisko ujścia Rodanu, wodnego szlaku komunikacyjnego łączącego port z resztą lądu oraz na brzegu Morza Śródziemnego, wzdłuż którego biegła trasa statków handlowych podróżujących z Wielkiej Grecji i Etrurii do hiszpańskiego Lewantu (Cunliffe, 2003, s. 66).

Kontakty handlowe i możliwości zysku nie stanowiły jedynej przyczyny zakładania nowych kolonii greckich na wybrzeżu zachodniej części basenu Morza Śródziemnego. Wydarzenia, które miały miejsce w jego wschodniej części i dotyczyły Fenicjan, Kartagińczyków i Greków, wpłynęły na kształt geografii politycznej w części zachodniej. W 574 r. miasta fenickie, takie jak Tyr i Sydon, zostały podbite przez Babilończyków, co osłabiło ich znaczenie polityczne oraz związki ze swoimi zamorskimi placówkami handlowymi. Sytuację wykorzystała Kartagina, która przejęła dotychczasowe fenickie rynki handlu w zachodniej części basenu Morza Śródziemnego. Od VI w. p.n.e. kontynuowała kolonizację na Półwyspie Iberyjskim (Villaricos, Almuñécar, Malaga i Kadyks). Skolonizowała także Ibizę (V-III w. p.n.e.) i Majorkę (Tuñón de Lara, Valdeón Baruque, Domínguez Ortiz, 1997, s. 29).

W 545 r. perskie wojska zaatakowały greckie państwa-miasta wschodniego wybrzeża Morza Egejskiego i kontynuowały działania wojenne aż do przegranej pod Salaminą w 480 r. p.n.e. i pod Platejami w 479 r. p.n.e. Fokajczycy nie potrafili pogodzić 
się z opanowaniem państw-miast wschodniego wybrzeża przez Persów. Ponieważ zdawali sobie sprawę z ich przewagi, zdecydowali się na migrację do swojej kolonii Massalii. Z jej pomocą założyli na Korsyce kolejną kolonię - Alalię, w miejscu umożliwiającym nawiązanie morskiej wymiany handlowej.

Etruskowie (szczególnie miasto Caere), którzy bali się odebrania im przez Fokajczyków dominującej pozycji w handlu, sprzymierzyli się z Kartagińczykami i stoczyli z Fokajczykami bitwę morską na Morzu Sardyńskim w 540 r. p.n.e. Przegrali, lecz mimo to Grecy, którzy ponieśli zbyt wysokie koszty tego zwycięstwa, opuścili Alalię i założyli nową kolonię Elea (Velia) w południowej Italii. Bitwa ta nie była potyczką bez znaczenia. Sojusz etrusko-kartagiński utrwalił się, co przypieczętowała wzajemna wymiana handlowa oraz wzmocnienie pozycji obu koalicjantów, zagrażających miastom Wielkiej Grecji. Massalia znalazła się w izolacji, co doprowadziło tamtejszych greckich kolonistów do prowadzenia polityki nastawionej na samowystarczalność oraz do zakładania nowych kolonii na terenie obecnej południowej Francji. Z czasem rosło jednak znaczenie miast Wielkiej Grecji, co pokazała klęska Etrusków w wojnie z Cumae w $525 \mathrm{r}$. p.n.e. i po raz drugi w 474 r. p.n.e., zamykając im drogę na południe. W VI w. p.n.e. na Morzu Tyrreńskim Etruskowie tracili dominującą rolę w tym regionie na rzecz Greków, byli więc zmuszeni skierować swą ekspansję w innym kierunku - na północ Półwyspu Apenińskiego (Tuñón de Lara, Valdeón Baruque, Domínguez Ortiz, 1997, s. 67-68).

W IV w. p.n.e. Kartagina praktycznie zmonopolizowała rynek handlowy w zachodniej części basenu Morza Śródziemnego. Kartagińczycy sprzymierzyli się z Rzymianami $\mathrm{w}$ walkach prowadzonych $\mathrm{z}$ greckimi kolonistami, a później z ludami italskimi (348 r. p.n.e., 306 r. p.n.e., 280 r. p.n.e.). Rzymianie podbili południową Italię i podobnie jak Kartagińczycy myśleli o dalszym powiększaniu swojego terytorium oraz o zdobyciu nowych rynków zbytu. Doszło do trzech wojen Rzymu z Kartaginą (I wojna punicka 264-241 r. p.n.e., II wojna punicka 218-202 r. p.n.e., III wojna punicka 149-146 r. p.n.e. - w Afryce Północnej) (Jaczynowska, 1995, s. 41-46). Od czasów wojen punickich wszystkie walki prowadzone przez Rzymian nie miały charakteru obronnego, ale były wynikiem chęci dominacji na Morzu Śródziemnym i stworzenia imperium (Jaczynowska, 1995, s. 46-49). W ciągu II w. p.n.e. Rzymianie stopniowo podporządkowali swojej władzy wszystkie plemiona zamieszkujące Italię (Senonów, Bojów, Insubrów, Cenomanów, Ligurów i Karnów) (Cunliffe, 2003, s. 256-257).

II wojna punicka (218-202 r. p.n.e.) stanowiła przełomowy okres dla polityki zewnętrznej Republiki rzymskiej. Ustanowienie kontroli nad obszarami poza Półwyspem Apenińskim i ustabilizowanie sytuacji w Italii z dala od potencjalnych zagrożeń stawało się coraz bardziej realne. Wojna $z$ Hannibalem uwidoczniła strategiczne znaczenie doliny Padu oraz wymusiła na Rzymianach przemieszczanie wojsk na Półwysep Iberyjski przez tereny południowej Galii (obecnej Prowansji i Langwedocji). Opanowanie nowych ziem zaspokoiłoby zapotrzebowanie na produkty, których brakowało na Półwyspie Apenińskim, takich jak surowce mineralne (sprowadzane głównie z Półwyspu Iberyjskiego, obecnej Kornwalii i północnej Francji) czy niewolników, stworzyłoby też rynki zbytu dla nadwyżek wyrobów italskich (np. wina i luksusowych przedmiotów codziennego użytku) (Cunliffe, 2003, s. 256-257). 
W wyniku II wojny punickiej Kartagina utraciła swoje posiadłości na Półwyspie Iberyjskim. W II w. p.n.e. Rzymianie rozpoczęli podbój tych ziem i zamieszkujących je plemion celtyberyjskich. W I w. p.n.e. wybuchła wojna domowa w Italii. Wydarzenia te doprowadziły do dużej mobilności wojsk, stale przegrupowywanych i przemieszczających się z Półwyspu Apenińskiego na Półwysep Iberyjski drogą lądową przez tereny południowej Galii. Kontakty handlowe między Hispanią a Italią utrzymywano raczej drogą lądową niż morską, a kupcy rzymscy podróżowali wraz z oddziałami żołnierzy. Celtycko-liguryjscy mieszkańcy Galii zaczęli brać bezpośredni udział w wymianie handlowej, nie, jak dotychczas, za pośrednictwem kupców greckich osiadłych w koloniach na wybrzeżu śródziemnomorskim. O kontaktach ludności tych ziem z Rzymianami świadczą elementy charakterystyczne dla rzymskiej architektury obecne w oppidach celtyckich w Ensérune, Entremont i Nages. Niektórzy kupcy rzymscy penetrowali dalsze zakątki Galii (oppida - Tolosa «Tuluza» nad Garonną oraz Vienna «Vienne» nad Rodanem). Dostrzegali możliwości handlowe, jakie stwarzały szlaki prowadzące wzdłuż Rodanu na północ oraz Aude-Carcassonne-Gap-Garonne na zachód. Problemem dla wymiany handlowej między Grekami, Ligurami i Celtami a Rzymianami okazały się ataki plemion zamieszkujących Alpy oraz dolinę dolnego Rodanu. W $123 \mathrm{r}$. p.n.e. doprowadziły one do aneksji południowej Galii i utworzenia prowincji rzymskiej zwanej Galią Zaalpejską (Gallia Narbonensis) (Cunliffe, 2003, s. 258-259).

W 122-121 r. p.n.e. Gnejusz Domicujsz Ahenobarbus stłumił powstanie galijskich plemion Allobrogów i Arwernów. W czasie walk komunikacja lądowa między Półwyspem Apenińskim a Iberyjskim była utrudniona. Założenie placówki handlowej - rzymskiej kolonii Narbo Martius w 118 r. p.n.e. w dużym stopniu odebrało dochody czerpane $\mathrm{z}$ handlu śródziemnomorskiego portom hiszpańskim. Kupcy italscy widzieli wówczas w Galii więcej możliwości zysku niż na Półwyspie Iberyjskim (Nolla i Brufau, Casas i Genover, 1984, s. 26).

Do I w. p.n.e. jedynie południowa część Galii znajdowała się w rękach rzymskich. W 59 r. p.n.e. Juliusz Cezar stał się zwierzchnikiem Galii Przedalpejskiej (Gallia Cisalpina) i Ilirii (Illyricum) oraz Galii Zaalpejskiej (Gallia Transalpina). Objął tym samym kontrolę nad terenami umożliwiającymi wejście na Półwysep Apeniński. Galia Zaalpejska z powodu swojego położenia była dobrym terenem, z którego można zacząć działania wojenne na północy i przyłączyć do niej zdobyte ziemie. O rozpoczęciu wojny zadecydowały poczynania germańskich plemion pod wodzą Ariowista, które doprowadziły do migracji Helwetów i innych plemion zamieszkujących rejony graniczące z Galią Przedalpejską. Kampania wojenna miała wyeliminować zagrożenie ze strony Germanów, którzy dostarczyli oficjalnych powodów do wojny i umożliwić późniejszą aneksję Galii oraz ochronić gospodarczy interes Rzymu. Zdobycie bogatych łupów wzmocniłoby autorytet Juliusza Cezara jako wodza oraz dostarczyłoby środków na spłacenie jego długów. Działania wojenne miały nie utrudniać prowadzenia działalności handlowej kupcom rzymskim. Główne rynki handlu w środkowej Galii funkcjonowały nadal, podczas gdy Cezar objął kontrolę nad północnym wybrzeżem - na obszarze między Renem a Loarą (Nolla i Brufau, Casas i Genover, 1984, s. 287-288). 
Juliusz Cezar określał tereny nieobjęte panowaniem rzymskim jako Gallia comata, zaś zromanizowaną Galię Zaalpejską jako Gallia togata. Plemiona celtyckie nazywane przez Rzymian Galami były bardzo zróżnicowane i rozbite politycznie oraz często ze sobą walczyły. W obrębie plemion dochodziło do walk o władzę między starszyzną a samozwańczymi władcami, przez co rozbicie wewnętrzne i kłótnie decydowały o ich słabości. Pod koniec lat siedemdziesiątych I w. p.n.e. Swebowie pod wodzą Ariowista pokonali Helwetów. Helwetowie musieli opuścić zajmowane przez siebie ziemie między Menem a górnym biegiem Renu i osiedlić się na obszarze graniczącym z Galią Przedalpejską (w zachodniej części obecnej Szwajcarii). W 58 r. p.n.e. Swebowie zmusili ich do dalszej wędrówki na zachód. Helwetowie poprosili o pozwolenie przejścia przez Galię Zaalpejską (Gallię Narbonensis). Juliusz Cezar nie zgodził się i w tym samym roku razem ze swoim wojskiem przekroczył granicę Galii Przedalpejskiej (Galli Cisalpińskiej), wchodząc na terytorium celtyckiej Galii. Helwetowie szli przez ziemie Sekwanów i Eduów. Rzymianie zaatakowali ich jako wrogów swoich sojuszników Eduów i zmusili do powrotu na tereny alpejskie (obecnie należące do Szwajcarii). Ariowist na czele Swebów przybył do Galii jako sojusznik Sekwanów, będących w stanie wojny z Eduami. Cezar pod pretekstem pomocy Eduom stoczył ze Swebami bitwę w okolicy Wogezów i wyparł ich za Ren. Następnie zimował na obszarze zajmowanym przez Sekwanów w Vescontio (Besançon) w 58-57 r. p.n.e. Z pomocą dwóch nowych legionów rozpoczął w 57 r. p.n.e. podbój północno-wschodniej Galii, należącej do Belgów. Legat Publiusz Krassus podbił Akwitanię (obszar na południe od Garonny). W $56 \mathrm{r}$. p.n.e. po ciężkiej wojnie Juliusz Cezar włączył całą Galię pod rzymskie panowanie, ale nie było to jednak ostateczne zwycięstwo. W 52 r. p.n.e. wybuchło powstanie galijskie. Udało się zjednoczyć dotychczas skłócone plemiona Galów. Dokonał tego Wercyngetoryks, młody wódz Arwernów. Po wyjątkowo ciężkich zmaganiach wojennych zakończonych oblężeniem Alezji Rzymianie podbili całą Galię. W $51 \mathrm{r}$. p.n.e. ustanowili na ziemiach galijskich nowe rzymskie prowincje (Jaczynowska, 1995, s. 157-159).

Gallia Narbonensis była pierwszym rejonem Galii włączonym pod panowanie rzymskie. Pozostałe części podbite przez Juliusza Cezara określano jako: Aquitania (obszar sąsiadujący z Galią Narbońską, obecne Midi-Pyrénées i Langwedocja-Rousillon), Gallia Celtica (środkowe i północno-zachodnie tereny dzisiejszej Francji) oraz Gallia Belgica (północno-wschodni rejon obecnej części północnej Francji oraz głównie Belgii). Wraz z wprowadzeniem rządów cesarskich przeprowadzono nowy podział administracyjny podległych Rzymowi ziem. W Galii utworzono cztery prowincje nazwane: Gallia Narbonensis (obecna Langwedocja i Prowansja), Aquitania (przylegająca na południu do dzisiejszego Midi-Pyrénées oraz środkowo-zachodni obszar Galii położony nad Atlantykiem), Gallia Lugdunensis (okalająca od wschodu Akwitanię, zajmująca leżącą nad Atlantykiem północno-zachodnią część obecnej Francji oraz jej wschodnią część, od południa graniczącą z Galią Narbońską) i Gallia Belgica (tereny dzisiejszej Belgii oraz wschodniej Francji, pas rozciągający się wzdłuż Galli Lugdunensis) (Cary, Hayes Scullard, 1992, s. 40). 
Podział administracyjny opierał się na dawnych podziałach plemiennych. Rzymianie zachowali lokalne struktury społeczne, gospodarcze i prawne. Celtyckie osady w zależności od swojego położenia - w pobliżu sieci dróg - albo przeobrażały się w ośrodki miejskie, albo z dala od węzłów komunikacyjnych - upadały. Zakładano również nowe miasta, wznoszono budowle użyteczności publicznej, budowano drogi i akwedukty. Galia romanizowała się. Przedstawiciele lokalnych elit mieli możliwość utrzymania znaczącej pozycji w miejscowych społecznościach, wzbogacenia się i częściowego dostępu do sprawowania rzymskich urzędów (Cunliffe, 2003, s. 308-309).

\section{AMFORY GALIJSKIE - TYPY ZNALEZISK I ICH CHARAKTERYSTYKA}

Początki uprawy winnej latorośli na terenach określanych w czasach rzymskich jako Gallia Narbonensis, a obejmujących dzisiejszą Langwedocję i Prowansję, sięgają VI w. p.n.e. Pierwszym i jedynym ośrodkiem produkującym wino przeznaczone na rynek lokalny była grecka kolonia Massalia (Marsylia). W VI-II w. p.n.e. w jej rejonie wytwarzano pierwsze galijskie amfory zwane massalskimi. Badania archeologiczne potwierdzają, że w czasach wcześniejszych nie istniała na tych terenach rodzima produkcja amfor i trudno także mówić o regularnej uprawie winorośli. Pierwsze znaleziska ceramiki tego typu to importy etruskie, greckie i punickie sprowadzane w małych, a nie w ogromnych ilościach (Laubenheimer, 1990, s. 25).

W ciągu pierwszego wieku po opanowaniu przez Rzymian w 123 r. p.n.e. ziem określanych jako Gallia Narbonensis nie produkowano na nich masowo wina przeznaczonego na eksport. Importowano italskie wino w dużych ilościach i wymieniano je na niewolników i metale z Galii. Senat rzymski postanowił, że na terenach kontrolowanych przez Rzymian i leżących poza Alpami nie wolno uprawiać oliwek i winnej latorośli (Laubenheimer, 1998, s. 166-167). Wspominał o tym Cyceron (106-43 r. p.n.e.) w De Republica (i chociaż nie potępiał tego typu polityki ze względu na wymierne korzyści, jakie przynosiła Rzymianom, nie usprawiedliwiał jej):

Kretejczycy i Etolowie mają za rzecz godziwą rozbój. Lacedemończycy mawiali, że własnością ich są wszystkie pola, których mogli dosięgnąć ostrzem swoich włóczni. Ateńczycy zwykli publicznie nawet przysięgać, że należy do nich wszelka ziemia, która rodzi oliwki i pszenicę. Galowie uważają za rzecz haniebną uprawę roli i dlatego z bronią w ręce zbierają zboże z cudzych pól. Przecież i my, choć uznajemy się za ludzi bardzo sprawiedliwych, nie pozwalamy ludom zaalpejskim na uprawianie oliwek i winorośli, by podnieść dochodowość naszych ogrodów oliwnych i winnic. W związku z tym mówi się o nas, że postępujemy roztropnie, lecz nikt nie powie, że postępujemy sprawiedliwie, z czego możecie pojąć, że roztropność jest czymś różnym od sprawiedliwości. ${ }^{1}$

${ }^{1}$ Marcus Tullius Cicero, ks. III, rozdz. 9, 1960, s. 121-122; a także w: Marcus Tullius Cicero, lib. III, capit. 9, 1955, s. 88: „Vitae vero instituta sic distant, ut Cretes et Aetoli latrocinari honestum putent, Lacedaemonii suos omnis agros esse dictitarint, quos spiculo possent attingere. Athenienses iurare etiam 


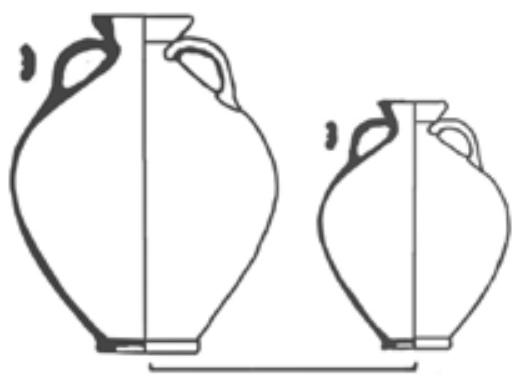

Gauloise 1

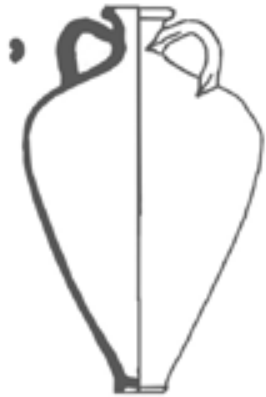

Gauloise 4

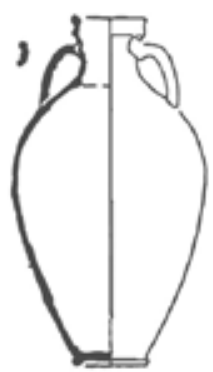

Gauloise 2

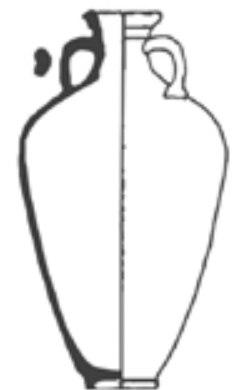

Gauloise 3

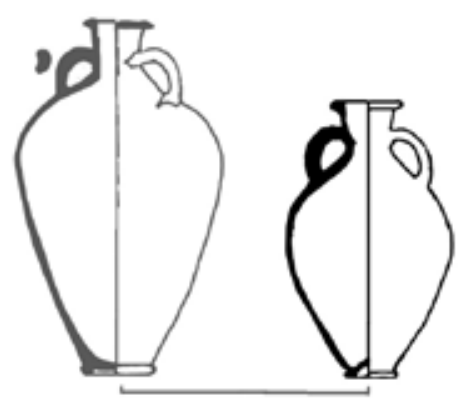

Gauloise 5

Ryc. 1. Amfory galijskie typu Gauloise 1, Gauloise 2, Gauloise 3, Gauloise 4, Gauloise 5 (F. Laubenheimer, Vins, huiles et sauces, Paris 1990, s. 166).

Fig. 1. Gallic amphorae of the type Gauloise 1, Gauloise 2, Gauloise 3, Gauloise 4, Gauloise 5 (F. Laubenheimer, Vins, huiles et sauces, Paris 1990, p. 166)

Od II w. do ostatnich dziesięcioleci I w. p.n.e. statki handlowe wypełnione winem wypływały z rzymskich portów nad morzem Tyrreńskim i dopływały do wybrzeży południowej Galii. Zarówno w oppidach galijskich (na stanowiskach archeologicznych w Tuluzie, Essalois i Bibracte w obecnej Langwedocji), jak i we wrakach rzymskich pochodzących z tego okresu znaleziono amfory Dressel 1, zawierające importowane wino italskie (Liou, 1990, s. 327-328). Pojemniki ceramiczne typu Dressel 1 wywodziły się z późnych amfor grecko-italskich i były produkowane na wybrzeżu tyrreńskim Półwyspu Apenińskiego, w Kampanii, Lacjum i Etrurii. Znamy kilka wariantów tej amfory określanej jako Dressel 1A, Dressel 1B i Dressel 1C (Laubenheimer, 1990, s. 40-41).

publice solebant omnem suam esse terram quae oleam frugesve ferret; Galli turpe esse ducunt frumentum manu quaerere, itaque armati alienos agros demetunt; nos vero instissimi homines, qui Transalpinas gentis oleam et vitem serere non sinimus, quo pluris sint nostra oliveta nostraeque vineae; quod cum faciamus, prudenter facere dicimur, iuste non dicimur, ut intellegatis discrepare ab aequitate sapientiam". 
W ostatnim dwudziestoleciu i trzydziestoleciu I w. p.n.e. można zauważyć, że na terenie Galii zmniejszyła się ilość amfor importowanych z Półwyspu Apenińskiego, co ma również związek ze zmniejszeniem eksportu wina italskiego do Galii i Hiszpanii. Pojemniki ceramiczne typu Dressel 2-4 zastąpiły Dressel 1 (Liou, 1990, s. 328).

Od końca I w. p.n.e. wzrosła produkcja wina hiszpańskiego. Prowincja Hispania Tarraconensis włączyła się do handlu śródziemnomorskiego i w okresie od końca I w. p.n.e. do około połowy II w. n.e. stała się najważniejszym producentem i eksporterem wina w zachodniej części Morza Śródziemnego (Keay 1987, s. 383-384).

W ostatnich dziesięcioleciach p.n.e. wina italskie zaczęły tracić monopol na rynku galijskim i na ten okres datuje się początki masowej uprawy winorośli oraz powstawania pierwszych warsztatów ceramicznych w Galii. Początkowo, w czasach panowania Oktawiana Augusta, wytwarzano imitacje italskich amfor na wino typu Dressel 1 i Dressel 2-4 (w Marsylii, Ardèche w Saint-Just, Lyonie) oraz imitacje amfor Pascual 1 z Hispanii Tarraconensis (np. w Montans «Tarn», Cornéilhan «Hérault», Sainte-Cécile-les-Vignes «Vaucluse» i w Marsylii) (Laubenheimer, 1998, s. 167).

Wkrótce coraz liczniej powstające warsztaty ceramiczne zaczęły produkować nie tylko imitacje amfor hiszpańskich czy italskich, ale rodzime galijskie amfory płaskodenne, z których pierwszą była amfora Gauloise 2 (Laubenheimer, 1990, s. 98-99). $\mathrm{W}$ rejonie Marsylii rozpoczęto produkcję amfor z płaskim dnem, określanych jako Gauloise 2 i eksportowanych w niewielkiej ilości na limes germański do zachodniej i centralnej Galii. I w. n.e. okazał się szczęśliwym okresem dla uprawy winorośli w Galii i wytwarzania wina, ponieważ Galia stała się ważnym producentem różnorodnych win o zróżnicowanej jakości i cenie (Laubenheimer, 1998, s. 167). W I i II w. na obszarze obecnej Langwedocji i Prowansji (należących w starożytności do Galii Narbonensis) produkowano 5 typów amfor określanych jako: Gauloise 1, Gauloise 2, Gauloise 3, Gauloise 4 i Gauloise 5 (Laubenheimer, 1990, s. 98-99). Należy również wspomnieć o trzech stanowiskach znajdujących się na obszarze Galii Narbonensis, na których znaleziono pozostałości amfor typu Dressel 7-11 (zasadniczo wytwarzanej na Półwyspie Iberyjskim). Chodzi o warsztaty ceramiczne w Sigean, Sallèles d'Aude i Velaux. Prawdopodobnie galijskiej Dressel 7-11 nie produkowano w dużych ilościach, co odzwierciedla dotychczasowy stan badań na tym terenie (Laubenheimer, 1985, s. 318).

Tabela, w której zebrano amfory na wino produkowane w Gallii Narbonensis w okresie II w. p.n.e. - II w. n.e. ${ }^{2}$

\footnotetext{
2 Tabela została sporządzona na podstawie następujących opracowań oraz artykułów: P. Dyczek, 1999, Amfory rzymskie z obszaru dolnego Dunaju. Dystrybucja amfor i transportowanych w nich produktów w I-III w. po Chr. Warszawa: IA UW; F. Laubenheimer, 1985, La production des amphores en Gaule Narbonnaise. Paris: Les Belles Lettres; F. Laubenheimer, 1990, Le temps des amphores en Gaule. Vins, huiles et sauces. Paris: Errance; J. Miró, 1990, El comercio del vino de la Tarraconense (s.I a.C.-I d.C.). Una síntesis. W: Le commerce maritime romain en Méditerranée occidentale, El comercio maritimo romano en el Mediterráneo occidental, Colloque international tenu à Barcelone du 16 au 18 mai 1988, Le Groupe PACT du Conseil de l'Europe La Societat Catalona d'Arqueologia, (s. 333) Strasbourg: Conseil
} 


\begin{tabular}{|c|c|c|c|}
\hline Typ amfory & Opis amfory & Datowanie & Obszar występowania \\
\hline Dressel 2-4 & $\begin{array}{l}\text { Wylew: szeroki, wychylony } \\
\text { na zewnątrz, o zaokrąglonym } \\
\text { brzegu } \\
\text { Szyjka: cylindryczna } \\
\text { Ramiona: krótkie i skośne } \\
\text { Imadła: przekrój o kształcie } \\
\text { połączonych kół } \\
\text { Brzusiec: gładki, najszerszy, } \\
\text { gdy łączy się z ramionami, } \\
\text { zwężający się ku dołowi } \\
\text { Stopka: stożkowata i pełna }\end{array}$ & $\begin{array}{l}\text { ok. } 30 \text { r. p.n.e. - } \\
150 \text { r. n.e. }\end{array}$ & $\begin{array}{l}\text { Miejsce produkcji: } \\
\text { Kampania, Latium i Etruria } \\
\text { (płw. Apeniński), obecna Ka- } \\
\text { talonia (Hispania Tarraconen- } \\
\text { sis), Betyka, pd. i środkowa } \\
\text { Galia, mniejsze ośrodki egej- } \\
\text { skie, Amay w obecnej Belgii } \\
\text { Dystrybucja: } \\
\text { Galia, Italia, Baleary, pn. } \\
\text { Afryka, Brytania }\end{array}$ \\
\hline $\begin{array}{l}\text { Dressel } \\
\text { 1-Pascual } 1 \\
\text { (kopia Dressel } \\
\text { 1B z Italii) }\end{array}$ & $\begin{array}{l}\text { Wylew: pionowy i wysoki } \\
\text { Szyjka: cylindryczna } \\
\text { Ramiona: podłużne i pionowe } \\
\text { Imadła: owalne w przekro- } \\
\text { ju, z rowkiem biegnącym po } \\
\text { zewnętrznej stronie } \\
\text { Brzusiec: owalny, wydłużony } \\
\text { Stopka: spiczasta }\end{array}$ & $\begin{array}{l}\text { poł. I w. p.n.e. - } \\
\text { I ćwierć I w. n.e. }\end{array}$ & $\begin{array}{l}\text { Miejsce produkcji: } \\
\text { obecna Katalonia, głównie jej } \\
\text { wybrzeże oraz pd. Francja (np. } \\
\text { Aspiran, Montpellier) } \\
\text { Dystrybucja: } \\
\text { Galia, płw. Apeniński, Bryta- } \\
\text { nia, limes germański }\end{array}$ \\
\hline Gauloise 1 & $\begin{array}{l}\text { Wylew: szeroki, zaokrąglony, } \\
\text { wyraźna forma kołnierza } \\
\text { Szyjka: bardzo krótka } \\
\text { Ramiona: krótkie, ukośne, } \\
\text { zaokrąglone } \\
\text { Imadła: półokrągłe w prze- } \\
\text { kroju } \\
\text { Brzusiec: wyraźnie kulisty, } \\
\text { lekko zwężony u dołu } \\
\text { Stopka: płaska }\end{array}$ & I w. n.e. & $\begin{array}{l}\text { Miejsce produkcji: } \\
\text { pd. Galia, głównie Prowansja, } \\
\text { szczególnie w dolinie Rodanu } \\
\text { i w pobliżu Marsylii } \\
\text { (np. Chusclan, Bagnols, } \\
\text { Tresques, Nîmes) } \\
\text { Dystrybucja: } \\
\text { Galia, głównie południowa } \\
\text { (dolina Rodanu), Brytania } \\
\text { (Londyn, Worcester) }\end{array}$ \\
\hline Gauloise 2 & $\begin{array}{l}\text { Wylew: szeroki } \\
\text { Szyjka: krótka } \\
\text { Ramiona: ukośne, półokrągłe } \\
\text { Imadła: półokrągłe w prze- } \\
\text { kroju } \\
\text { Brzusiec: zaokrąglony, zwęża- } \\
\text { jący się ku dołowi } \\
\text { Stopka: płaska }\end{array}$ & $\begin{array}{l}\text { koniec I w. } \\
\text { p.n.e. - początek } \\
\text { I w. n.e. }\end{array}$ & $\begin{array}{l}\text { Miejsce produkcji: } \\
\text { Gallia Narbonensis (Langwe- } \\
\text { docja, Prowansja, szczególnie } \\
\text { okolice Marsylii) } \\
\text { Dystrybucja: } \\
\text { Gallia Narbonensis }\end{array}$ \\
\hline Gauloise 3 & $\begin{array}{l}\text { Wylew: szeroki kołnierz } \\
\text { Szyjka: krótka } \\
\text { Ramiona: ukośne, krótkie } \\
\text { Imadła: półokrągłe w prze- } \\
\text { kroju } \\
\text { Brzusiec: zaokrąglony, ale } \\
\text { zwężający się ku dołowi } \\
\text { Stopka: płaska }\end{array}$ & I w. n.e. & $\begin{array}{l}\text { Miejsce produkcji: } \\
\text { Gallia Narbonensis (np. } \\
\text { warsztat ceramiczny w Corne- } \\
\text { ilhan w l'Hérault) } \\
\text { Dystrybucja: } \\
\text { obecna Francja, Szwajcaria } \\
\text { i Niemcy }\end{array}$ \\
\hline
\end{tabular}

de l'Europe; D. P. S. Peacock, D. F. Williams, 1986-1991, Amphorae and the Roman economy, LondonNew York: Longman. 


\begin{tabular}{|c|c|c|c|}
\hline $\begin{array}{l}\text { Gauloise } 4 \\
\text { (Pélichet 47) }\end{array}$ & $\begin{array}{l}\text { Wylew: zaokrąglony, wywinię- } \\
\text { ty na zewnątrz } \\
\text { Szyjka: krótka } \\
\text { Ramiona: krótkie i ukośne } \\
\text { Imadla: półokrągłe w prze- } \\
\text { kroju } \\
\text { Brzusiec: zaokrąglony, zwę- } \\
\text { żający się ku dołowi, wyraźnie } \\
\text { większa górna część brzuśca } \\
\text { niż dolna } \\
\text { Stopka: płaska }\end{array}$ & $\begin{array}{l}\text { poł. I w. n.e. - } \\
\text { II-III w. n.e. }\end{array}$ & $\begin{array}{l}\text { Miejsce produkcji: } \\
\text { Langwedocja i Prowansja } \\
\text { Dystrybucja: } \\
\text { Galia, Brytania, Germania, } \\
\text { Italia }\end{array}$ \\
\hline Gauloise 5 & $\begin{array}{l}\text { Wylew: wylew o zaokrąglo- } \\
\text { nym brzegu } \\
\text { Szyjka: krótka } \\
\text { Ramiona: ukośne i półokrągłe } \\
\text { Imadła: półokrągłe w prze- } \\
\text { kroju } \\
\text { Brzusiec: zaokrąglony, zwęża- } \\
\text { jący się ku dołowi } \\
\text { Stopka: płaska }\end{array}$ & $\begin{array}{l}\text { II poł. I w. n.e. - } \\
\text { trzy pierwsze } \\
\text { ćwierci II w. n.e. }\end{array}$ & $\begin{array}{l}\text { Miejsce produkcji: } \\
\text { Gallia Narbonensis, raczej } \\
\text { Prowansja (np. Fréjus-Pauva- } \\
\text { dou, Istres, Viens i Marsylia) } \\
\text { Dystrybucja: } \\
\text { Galia, Ostia, rzadko w Bryta- } \\
\text { nii (York, Leicester) }\end{array}$ \\
\hline
\end{tabular}

Powyższa tabela obejmuje rodzime amfory na wino produkowane w warsztatach Gallii Narbonensis na obszarze:

- obecnej Langwedocji: Gauloise 2, Gauloise 3, Gauloise 4

- i Prowansji: Gauloise 1, Gauloise 2, Gauloise 3, Gauloise 4, Gauloise 5 oraz amfory wzorowane na italskich i hiszpańskich: Dressel 1-Pascual 1 i Dressel 2-4.

\section{PODSUMOWANIE}

Znaleziska archeologiczne potwierdzają tezę, że pierwszym ważnym producentem wina w handlu śródziemnomorskim w zachodniej części basenu Morza Śródziemnego była Italia (czasy Republiki rzymskiej), następnie Hispania Tarraconensis, która zdominowała rynek w I w. n.e., a potem Galia, na której południowych obszarach, szczególnie w II w. n.e., na masową skalę wytwarzano wino i produkowano amfory.

W okresie IV-II w. p.n.e. rdzenni mieszkańcy Galii (plemiona celtyckie) nie uprawiali winorośli i nie produkowali wina. Koloniści greccy jako pierwsi założyli winnice i zajęli się handlem na potrzeby lokalnych rynków zbytu. Kupcy greccy, a później etruscy sprowadzali do Galii greckie i italskie wino. W okresie II - koniec I w. p.n.e. Rzymianie zmonopolizowali handel winem w Galii, zaś w ostatnich dziesięcioleciach p.n.e. zaczęto produkować rodzime wino galijskie. W I w.n.e. na masową skalę importowano wino hiszpańskie. W okresie połowy/końca I - końca II w. n.e. wino galijskie zmonopolizowało, tak jak wcześniej wina italskie i hiszpańskie, rynki handlowe Galii, Hiszpanii i Italii. 
Odtworzenie obrazu kontaktów handlowych i roli Galii w czasach rzymskich opiera się na badaniach materiału ceramicznego znalezionego w warsztatach garncarskich, w pozostałościach wiejskich i miejskich domów, villi, zabudowań gospodarczych, śmietniskach, we wrakach rzymskich statków handlowych zatopionych w Morzu Śródziemnym, na morskich śmietniskach czy w dawnych portach rzymskich. Analiza formy naczyń, składu chemicznego materiału, z którego je zrobiono, określenie czasu ich występowania, rozmieszczenia geograficznego znalezisk, ustalenia miejsc produkcji i zasięgu dystrybucji (dzięki analizie stempli i tituli picti umieszczanych na amforach) oraz obliczenia ilości znanych nam tego typu znalezisk ceramicznych umożliwiła stworzenie klasyfikacji amfor produkowanych w Galii, a wraz z kolejnymi znaleziskami i sukcesywnie opracowywanymi wynikami badań archeologicznych prowadzonych na różnorodnych stanowiskach pozwala budować prawdopodobny obraz Galii - producenta wina obecnego na rzymskich stołach zachodniej części Imperium Romanum.

Tabela zawierająca stanowiska, na których znaleziono na tyle dużą ilość rodzimych amfor galijskich, że mogły stanowić wiarygodny materiał porównawczy do analizy ceramiki.

\begin{tabular}{|c|c|c|c|c|c|c|c|c|c|}
\hline \multirow[b]{2}{*}{ Stanowisko } & \multicolumn{9}{|c|}{ Typ stanowiska } \\
\hline & $\begin{array}{l}\text { warsz- } \\
\text { tat } \\
\text { cera- } \\
\text { micz- } \\
\text { ny }\end{array}$ & $\begin{array}{c}\text { villa } \\
\text { rzym- } \\
\text { ska }\end{array}$ & $\begin{array}{c}\text { budy- } \\
\text { nek } \\
\text { miesz- } \\
\text { kalny }\end{array}$ & $\begin{array}{l}\text { stud- } \\
\text { nia }\end{array}$ & $\begin{array}{l}\text { śmiet- } \\
\text { nisko }\end{array}$ & $\begin{array}{c}\text { droga } \\
\text { rzym- } \\
\text { ska }\end{array}$ & port & $\begin{array}{c}\text { wrak } \\
\text { statku } \\
\text { han- } \\
\text { dlo- } \\
\text { wego }\end{array}$ & $\begin{array}{c}\text { śmiet- } \\
\text { nisko } \\
\text { mor- } \\
\text { skie }\end{array}$ \\
\hline Aspiran (Hérault) & $\mathrm{x}$ & $\mathrm{x}$ & & & $\mathrm{x}$ & & & & \\
\hline $\begin{array}{l}\text { Bagnols-sur-Cèze } \\
\text { (Gard) }\end{array}$ & $\mathrm{x}$ & & & & & & & & \\
\hline Cavaillon & & & $\mathrm{x}$ & & & & & & \\
\hline $\begin{array}{l}\text { Corneilhan } \\
\text { (Hérault) }\end{array}$ & $\mathrm{x}$ & & & & & & & & \\
\hline Chusclan (Gard) & $\mathrm{x}$ & & & & & & & & \\
\hline Fréjus (Var) & $\mathrm{x}$ & & $x$ & & $\mathrm{x}$ & & & & \\
\hline $\begin{array}{l}\text { Istres (Bouches- } \\
\text {-du-Rhone) }\end{array}$ & $\mathrm{x}$ & & & & & & & & \\
\hline $\begin{array}{l}\text { Lansargues } \\
\text { (Hérault) }\end{array}$ & & & & $\mathrm{x}$ & & & & & \\
\hline Laurens (Hérault) & $\mathrm{x}$ & & & & & & & & \\
\hline Meynes (Gard) & $\mathrm{x}$ & & & & & & & & \\
\hline Montans (Tarn) & $\mathrm{x}$ & & & & & & & & \\
\hline $\begin{array}{l}\text { Montbazin } \\
\text { (Hérault) }\end{array}$ & $\mathrm{x}$ & & & & & & & & \\
\hline
\end{tabular}




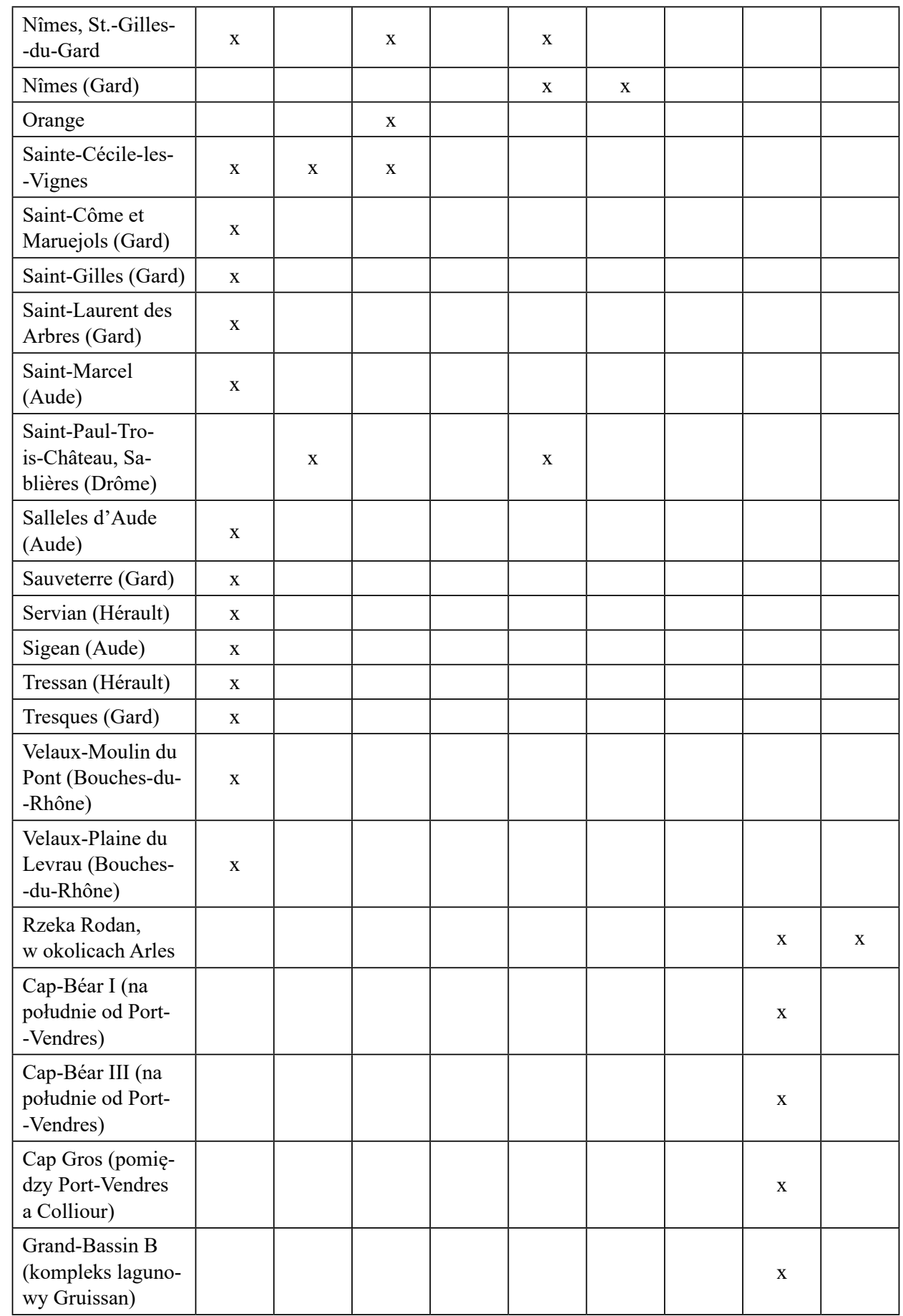




\begin{tabular}{|l|l|l|l|l|l|l|l|c|c|}
\hline $\begin{array}{l}\text { Grazel A (kom- } \\
\text { pleks lagunowy } \\
\text { Gruissan) }\end{array}$ & & & & & & & & $\mathrm{x}$ & \\
\hline $\begin{array}{l}\text { Mateille C (kom- } \\
\text { pleks lagunowy } \\
\text { Gruissan) }\end{array}$ & & & & & & & & & $\mathrm{x}$ \\
\hline Narbonne (Malard) & & & & & & & $\mathrm{x}$ & & \\
\hline $\begin{array}{l}\text { Narbonne (Port la } \\
\text { Nautique, Aude) }\end{array}$ & & & & & & & $\mathrm{x}$ & & $\mathrm{x}$ \\
\hline Port-Vendres II & & & & & & & & $\mathrm{x}$ & \\
\hline Port-Vendres IV & & & & & & & & $\mathrm{x}$ & \\
\hline Port-Vendres V & & & & & & & & $\mathrm{x}$ & \\
\hline
\end{tabular}

Poniższa tabela zawiera przykładowe stemple właścicieli amfor wyprodukowanych w czasach rzymskich w warsztatach Galii Narbonensis (z obecnej Langwedocji) oraz stempel z amfor importowanych w dużej ilości z Kampanii (M.PORC), znajdowanych na całym obszarze Galii ${ }^{3}$.

\begin{tabular}{|l|l|l|l|}
\hline \multicolumn{1}{|c|}{ Typ amfor } & \multicolumn{1}{|c|}{$\begin{array}{c}\text { Stemple } \\
\text { na amforach }\end{array}$} & \multicolumn{1}{|c|}{$\begin{array}{c}\text { Miejsce znalezienia } \\
\text { ceramiki }\end{array}$} & \multicolumn{1}{c|}{$\begin{array}{c}\text { Pochodzenie } \\
\text { amfory }\end{array}$} \\
\hline Pascual 1 & ATEP & $\begin{array}{l}\text { Aspiran (Hérault) - Langwe- } \\
\text { docja }\end{array}$ & $\begin{array}{l}\text { Aspiran (Hérault) - Langwe- } \\
\text { docja }\end{array}$ \\
\hline Pascual 1 & LAETI & $\begin{array}{l}\text { Aspiran (Hérault) - Langwe- } \\
\text { docja }\end{array}$ & $\begin{array}{l}\text { Aspiran (Hérault) - Lang- } \\
\text { wedocja }\end{array}$ \\
\hline Pascual 1 & TARN, TARANI & $\begin{array}{l}\text { Aspiran (Hérault), Montans } \\
\text { (Tarn) - Langwedocja }\end{array}$ & $\begin{array}{l}\text { Aspiran (Hérault), Montans } \\
\text { (Tarn) - Langwedocja }\end{array}$ \\
\hline Dressel 2-4 & MARI & Fréjus (Var) - Langwedocja & Fréjus (Var) - Langwedocja \\
\hline Dressel 2-4 & M.IUL.LICINIUS & $\begin{array}{l}\text { Fréjus (Var) - rejon } \\
\text { Saint-Lambert i Valescure } \\
\text { w Langwedocji }\end{array}$ & $\begin{array}{l}\text { Fréjus (Var) - rejon Saint- } \\
\text {-Lambert i Valescure w Lan- } \\
\text { gwedocji }\end{array}$ \\
\hline $\begin{array}{l}\text { Dressel 7-13, } \\
\text { Gauloise 1 }\end{array}$ & CLAR & $\begin{array}{l}\text { Lansargues (Hérault), Nî- } \\
\text { mes, Saint-Paul-Trois-Châte- } \\
\text { aux, Sablières (Drôme) }\end{array}$ & Nîmes w Langwedocji \\
\hline
\end{tabular}

${ }^{3}$ Tabela została sporządzona na podstawie: M. Beltrán Lloris, 1987, El comercio del vino antiguo en el valle del Ebro, I Colloqui d'arqueologia romana. El vi a l'antiguitat, economia, producció i comerç al Mediterrani occidental. Actes, museu de Badalona. Monografies badalonines, 9, 56; M. Comas Solà, 1987, Importació i exportació de vi a Baetulo: l'Estudi de les àmfores, I Colloqui d'arqueologia romana. El vi a l'antiguitat, economia, producció i comerç al Mediterrani occidental. Actes, Museu de Badalona. Monografies Badalonines, 9, 171; F. Laubenheimer, 1985, La production des amphores en Gaule Narbonnaise, Paris: Les Belles Lettres; J. Miró, 1987, Vi catala a França (segles I a.C.-I d.C.). Una síntesi preliminar, I Colloqui d'arqueologia romana, El vi a l'antiguitat economia producció i comerç al Mediterrani occidental. Actes, Museu de Badalona. Monografies Badalonines, 9, 250. 


\begin{tabular}{|l|l|l|l|}
\hline Gauloise 1 & EPPI & Nîmes & Nîmes \\
\hline Gauloise 1 & PATB & Nîmes & Nîmes \\
\hline Gauloise 1 & LIA & Nîmes & Nîmes \\
\hline Gauloise 1 & TVG & Nîmes & Nîmes \\
\hline Gauloise 1 & VERI & $\begin{array}{l}\text { Nîmes, Lansargues } \\
\text { (Hérault), Nîmes, Saint-Paul- } \\
\text {-Trois-Châteaux, Sablières } \\
\text { (Drôme) }\end{array}$ & Nîmes \\
\hline Gauloise 1 & $\begin{array}{l}\text { CN.ET T.SAC- } \\
\text { CON I I }\end{array}$ & $\begin{array}{l}\text { Nîmes, Saint-Gilles (Gard) - } \\
\text { Langwedocja }\end{array}$ & $\begin{array}{l}\text { Nîmes, Saint-Gilles (Gard) - } \\
\text { Langwedocja }\end{array}$ \\
\hline Sauloise 1 & SIS & $\begin{array}{l}\text { Nîmes, Lansargues } \\
\text { (Hérault), Nîmes, Saint-Paul- } \\
\text {-Trois-Châteaux, Sablières } \\
\text { (Drôme) }\end{array}$ & Nîmes \\
\hline Gauloise 4 & MARTIAL & Salleles d'Aude (Aude) & Salleles d'Aude (Aude) \\
\hline Gauloise 1 & L.H. & Tresques (Gard) & Tresques (Gard) \\
\hline Pascual 1 & M.PORC & $\begin{array}{l}\text { Narbonne, a także: } \\
\text { Bordeaux, Ste. Foy, Le } \\
\text { Mas-d'Agenais, Agen, } \\
\text { Albias, Lamothe-Capdeville, } \\
\text { Lectoure, Lescar, Saint-Jean- } \\
\text { de-Castex, Toulouse, Vieille } \\
\text { Toulouse, Enserune, Bram, } \\
\text { Auterive, Port-la-Nautique } \\
\text { (Narbonne), Ruscino-Per- } \\
\text { pignan }\end{array}$ & Italia (Kampania), Pompeje \\
\hline
\end{tabular}

O ile w I w. n.e., a szczególnie w jego pierwszej połowie, warsztaty galijskie produkowały imitacje amfor z Hispanii Tarraconensis typu Pascual 1, o tyle w okresie od końca I w. n.e. do końca III w. n.e. w Hispanii Tarraconensis wytwarzano imitacje Gauloise 4. Potwierdzają to wyniki badań archeologicznych prowadzonych na obszarze Hispanii Tarraconensis (obecnej Katalonii). Wzorowanie się na pojemnikach ceramicznych z Galii dobitnie świadczy o zapotrzebowaniu właśnie na tego typu amfory, o ich wartości użytkowej i popularności na rynku handlu winem (Revilla, 2000-2001, s. 212).

Gallia Narbonensis stała się jedną z bogatszych prowincji rzymskich. Warunki naturalne i dogodne położenie geograficzne sprzyjały rozwojowi rolnictwa i kontaktom handlowym z pozostałymi obszarami Imperium Romanum. Włączenie się do śródziemnomorskiego handlu dało południowej Galii pozycję głównego producenta i eksportera wina w zachodniej części basenu Morza Śródziemnego w okresie połowa/koniec I-II w. n.e. 


\section{BIBLIOGRAFIA}

Beltrán-Lloris, M.

1987 El comercio del vino antiguo en el valle de Ebro, I Colloqui d'arqueologia romana. El vi a l'antiguitat, economia, producció i comerç al Mediterrani occidental. Actes Museu de Badalona. Monografies Badalonines, 9, 51-73.

Cary, M., Hayes Scullard, H.

1992 Dzieje Rzymu. Warszawa: PIW.

Comas i Solà, M.

1987 Importació i exportació de vi a Baetulo: l'estudi de les àmfores, I Colloqui d'arqueologia romana. El vi a l'antiguitat, economia, producció i comerç al Mediterrani occidental. Ac-

Cunliffe, B. tes Museu de Badalona. Monografies Badalonines, 9, 161-173.

2003 Starożytni Celtowie. Warszawa: PIW.

Dyczek, P.

1999 Amfory rzymskie z obszaru dolnego Dunaju. Dystrybucja amfor i transportowanych Jaczynowska, M.

w nich produktów w I-III w. po Chr. Warszawa: IA UW.

1995 Dzieje Imperium Romanum. Warszawa: PWN.

Keay, S.

1987 La importacion de vino y aceite en la Tarraconense oriental en la antigüedad, I Colloqui d'arqueologia romana. El vi a l'antiguitat economia producció i comerç al Mediterrani occidental. Actes. Museu de Badalona. Monografies Badalonines, 9, 383-394.

Kornatowski, W. (przekł.)

1960 Marcus Tullius Cicero, O państwie. O prawach. O powinnościach. O cnotach, t. 2. Kraków: PWN.

Laubenheimer, F.

1998 Les amphores de la Gaule romaine, état de la question. Revue archéologique, 1, 164-175.

1985 La production des amphores en Gaule Narbonnaise. Paris: Les Belles Lettres.

1990 Le temps des amphores en Gaule. Vins, huiles et sauces. Paris: Errance.

Liou, B.

1990 Sur les amphores et le commerce du vin. W: Le commerce maritime romain en Méditerranée occidentale. El comercio marítimo romano en el Mediterráneo occidental. Colloque international tenu à Barcelone du 16 au 18 mai 1988, Le Groupe PACT du Conseil de l'Europe La Societat Catalona d'Arqueologia (s. 327-332). Strasbourg: Conseil de l'Europe.

Miró, J.

1987 Vi catala a frança (segles I a.C-I d.C.). Una síntesi preliminar, I Colloqui d'arqueologia romana. El vi a l'antiguitat economia producció i comerç al Mediterrani occidental. Actes. Museu de Badalona. Monografies Badalonines, 9, 249-268.

1990 El comercio del vino de la Tarraconense (s.I a.C.-I d.C.). Una síntesis. W: Le commerce maritime romain en Méditerranée occidentale. El comercio marítimo romano en el Mediterráneo occidental. Colloque international tenu à Barcelone du 16 au 18 mai 1988, Le Groupe PACT du Conseil de l'Europe La Societat Catalona d'Arqueologia (s. 333-354). Strasbourg: Conseil de l'Europe.

Nolla Brufau, J. M., Casas Genover, J.

1984 Algunes consideracions entorn de la romanització al N. E. de Catalunya. W: J. M. Nolla Brufau, J. Casas Genover (red.), Carta arqueologica de les comarques de Girona. El poblament d'época romana al nord-est de Catalunya. Girona: Museu Arqueologia de Catalunya-Girona. 
Peacock, D. P. S., Williams, D. F.

1991 Amphorae and the Roman economy an introductory guide. London - New York: Longman.

Revilla, V.

2000-2001 Nuevos tituli picti vinarios del litoral noreste de la Hispania Citerior, Pyrenae, 31-32, 209-216.

Tuñón de Lara, M., Valdeón Baruque, J., Domínguez Ortiz, A.

1997 Historia Hiszpanii. Kraków: Universitas.

Ziegler K. (wyd.)

1955 Marcus Tullius Cicero, De re publica - librorum sex. Lipsk: B. G. Teubner Verlag.

\section{ROLE OF SOUTHERN GAUL IN WINE PRODUCTION AND TRADE IN 6th CENTURY B.C. - 2th CENTURY A.D. IN THE LIGHT OF POLITICAL CHANGES IN THE WESTERN MEDITERRANEAN}

\section{Su m mary}

The reconstruction of how the trade contacts of Gaul looked like and what role Gaul played in Roman times is based on the research of ceramic material found in pottery workshops, in the remains of rural and urban houses, villae, farm buildings, garbage dumps, in the wrecks of Roman merchant ships sunk in the Mediterranean, in sea dumps and in ancient Roman ports. The analysis of the form of the vessels, the chemical composition of the material which they were made of, the determination of the time of their occurrence, the geographical distribution of the finds, the determination of the places of their production and their distribution range (thanks to the analysis of stamps and tituli picti placed on amphorae) and the calculation of the number of such ceramic finds known to us, made it possible to create the classification of amphorae produced in Gaul. Together with subsequent finds and successively developed results of archaeological research conducted at various sites, it allowed to build a probable and reliable image of Gaul - a producer of wine which was present on the Roman tables of the western part of the Roman Empire.

Southern Gaul, inhabited by Celtic tribes, became successively the area of commercial interests of the Etruscans and the Greeks, and later the Romans. While Etruscan merchants limited themselves only to maintaining economic contacts with the Gauls, Greek settlers established their colonies in Gaul and began to cultivate vines they had brought with them and to produce wine for local needs. Due to its geographic location, Massalia (Marseille), which was established in the 6th century $\mathrm{BC}$, became the most important Greek colony.

During the civil war in Italy and the conquest of the Iberian Peninsula by the Romans, Roman armies, together with merchants, moved through the lands of Gaul. The Romans became interested in these lands for political and economic reasons. They thought not only about searching for new markets, but also about the successive expansion of their country. In $118 \mathrm{BC}$ they founded the trading post of Narbo Martius (Narbonne) and Gallia Narbonensis became the first region of Gaul to be incorporated into Roman rule. In $51 \mathrm{BC}$ the Gallic lands became part of the Roman Empire and one of its income-producing provinces.

In the last decades BC Italian wines began to lose their monopoly on the Gallic market and this period marks the beginnings of mass viticulture and the establishment of the first ceramic workshops in Gaul. Soon, more and more ceramic workshops started to appear and produce not only imita- 
tions of Spanish or Italian amphorae (Dressel 2-4 and Dressel 1-Pascual 1), but also native Gallic flat-bottomed amphorae, the first of which was Gauloise 2. Gaul became an important producer of various wines of varied quality and price. During the 1st and 2nd centuries AD, Roman Gaul produced wine stored in the Gauloise 1, Gauloise 2, Gauloise 3, Gauloise 4 and Gauloise 5 flat-bottomed amphorae, which are unique to this area of the Roman Empire. In the mid/end of the 1st-2nd century AD Gaul became a major exporter of wine in the Western Roman Empire. 
